\title{
SÁNDOR Tímea
}

\section{VEZETŐFEJLESZTÉS HATÉKONYAN}

A vizsgálat célja feltérképezni a $360^{\circ}$-os visszajelzés önértékelésének eredményei alapján a személyiségjegyek és az érzelmi intelligencia összefüggéseit. A vizsgálat helye a Linamar Hungary Zrt., a vizsgált személyek egy középvezetôi munkakör munkavállalói ( $\mathrm{N}=42)$. A konfliktuskezelés, a meggyôzési készség, a problémamegoldás, az ellenôrzés, a feleloosségvállalás, a precizitás, a szorgalom és a teljesítménymenedzsment esetén, ha valaki önmaga szerint jó ezekben a vezetôi kompetenciákban, akkor magas EQ-pontszámot ért el. A vezetôi kompetenciák fejlesztése segítheti az érzelmi intelligencia fejlódését és fordítva, az érzelmi intelligencia és a személyiségtényezốk megfelelố komponenseinek fejlesztése a vezetối kompetenciák bizonyos fejlődését eredményezheti. ${ }^{1}$

Kulcsszavak: vezetôi kompetenciák, $\mathbf{3 6 0}^{\circ}$-os visszajelzés, érzelmi intelligencia, személyiség, kiválóan teljesítốk

McClelland és Boyatzis (1980) a kiválóan teljesítók között olyan motívumokat, szerepeket keresettek, amelyek kapcsolatban állnak a kiváló és hatékony teljesítménnyel. Az „input” megközelítés hívei, Spencer és Spencer (1993) személyiségvizsgálatokkal kapcsolatos kompetenciamodellt hozott létre. Az „outcome” megközelítés hívei azt vallják, hogy a hatékony teljesítményt nem az egyén viselkedése, hanem a munkakörhöz tartozó feladatok hatékony ellátása bizonyítja, és ezeknek a teljesítéseknek az értékét kell figyelembe venni (Eraut, 1994; Martin - Staines, 1994). A vezetói kompetenciák vizsgálata esetén a kompetencia szó fogalmi tisztázása elsődleges. A szakirodalomban rengeteg megfogalmazást találhatunk a kompetenciáról (például: Woodruffe, 1993; Klemp - McClelland, 1986; Spencer - Spencer, 1993; Boyatzis, 1982). A kompetencia Woodruffe (1993: 29. o.) szerinti megfogalmazása a következő: „A kompetencia a viselkedésminták egy készlete, melyet a munkakör betöltőjének be kell vetnie ahhoz, hogy a munkaköri feladatokat és funkciókat kompetensen lássa el." Ezen elmélet és az ehhez hasonló elméletek a kompetencia egy részét a kiváló teljesítményhez kötik, és olyan alapvető személyiségrésznek tartják, amik helyzettól függetlenül valószínúsítik a viselkedést (Szelestey, 2012). A kompetencia fogalmának vizsgálata alkalmával fontos elkülöníteni a kompetenciát (competency) és a kompetenciaterületeket (areas of competence; idézi: Szelestey, 2012). Kompetenciák ebben az értelemben azok a tulajdonságok, amelyekkel a munkakörhöz tartozó aspektusokat a személynek kompetens módon kell teljesítenie (Szelestey, 2012). Ezek olyan viselkedések, amik a mun- kakör hatékony ellátásához szükségesek. A kompetenciaterület kifejezés azokra a munkaköri aspektusokra utal, amelyeket a munkakör betöltôjének kompetens módon kell teljesítenie (Szelestey, 2012). A kompetencia tehát egy személyorientált kifejezés, míg a kompetenciaterület egy munkakör-orientált kifejezés, ami a munkaköri feladatok, funkciók elemzésével vezethetô le (Szelestey, 2012). Szelestey (2012: 6. o. idézi: Woodruffe, 1993) szerint ,a két fogalmat semmiképp nem szabad összekeverni, mindig különválasztva kell ôket kezelni”. A kompetencia fogalma mellett a kompetencia alkotóelemeinek áttekintése esetén szintén különböző elméletek közül választhatunk (például: Sveiby, 2001; Jakó, 2003; Legge - Barber,1982; Tóthné, 2000; Kővári, 1991; Spencer Spencer, 1993 idézi: Pató, 2006).

Ezen elméletek közül talán a legismertebb a Spencer, McClelland, Spencer (1990) által kidolgozott és az 1. ábrán látható jéghegymodell (idézi: Szászvári, 2008).

1. ábra

A jéghegymodell

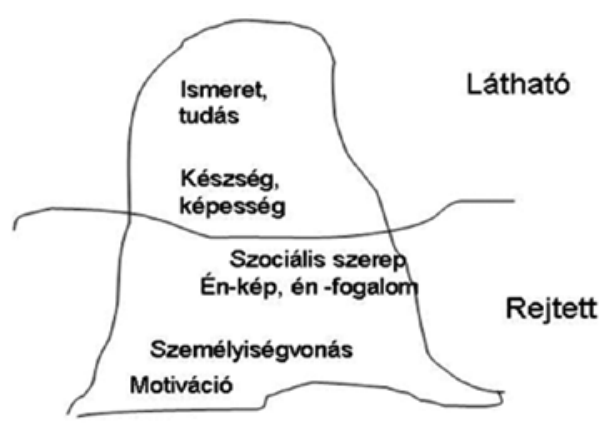

Saját forrás Spencer, McClelland, Spencer (1990) alapján 


\section{A jéghegymodell felépítése}

1. legalsó szinten a motiváció: a cselekvés, viselkedés hátterében álló hajtóerố, vágyak, kívánságok,

2. állandó személyiségvonás: a személyiség állandó/ stabil dimenziója; szervezett, gondolati, érzelmi jellemvonás; helyzetekre, észlelt információkra adott válasz,

3. énkép/énfogalom: a személy önmagáról alkotott képe; milyennek látja, gondolja magát, a világ észlelését és a viselkedést befolyásolja; a személy értékei, attitúdjei,

4. készség, képesség: gyakorlatban alkalmazható megnyilvánulások készlethalmaza, a tudatos tevékenység automatizált része, amely gyakorlás útján jön létre, fizikai és szellemi feladatok teljesítésének képességét adják,

5. ismeret, tudás: az egész életen át felhalmozódó tudatos vagy tudattalan tapasztalat.

A kompetenciákról elmondhatjuk, hogy hatással vannak a munkakör valamely területére, korrelálnak a hatékony munkateljesítménnyel, mérhetôk és fejleszthetốk, ezért a kidolgozott kompetenciamodell segít az objektív kiválasztási rendszerek kidolgozásában, a teljesítményértékelő rendszer megalkotásában és a tréningek típusának és felépítésének meghatározásában (Chong, 2001, idézi: Szelestey, 2012). Leplat (idézi: Szögi, 1997) szerint a kompetencia jellemzói a következók: operatív és cselevési, tanult, senki sem születik kompetensnek, strukturált, kombinálja az elemeit (tudást know-howt, következtetés, elvont fogalom, nem megfigyelhetô, csak a cselekvései, a magatartások és az eredmények. „A kompetencia az ismeretet akcióvá alakítja át, a know-how hidat képez valaminek a tudása és a megvalósítása között. A tudni elsôsorban a tanultak felhasználásának képessége, egy probléma megoldására vagy egy helyzet tisztázására való mozgósítását jelenti" (Szelestey, 2012: 7. o.). Ezenkívül sok megfogalmazás érvényes a kompetenciákra, de minden esetben tudást, cselekvési képességet fogalmaznak meg. Közös bennük az is, hogy a személyiség fontos vonásaival nem foglalkoznak, és nem tekintik a tudás részének a munkavégzéshez szükséges kondíciót, a terhelés elviselésének képességét sem, ez csak egy része a kompetenciának (Szelestey, 2012). Brown (1994) szerint vannak olyan kompetenciák, amik metakompetenciák. Szelestey (2012) szerint a metakompetenciák olyan személyiségjellemzók, melyek az egyén által fejleszthetố kompetenciák felett állnak, ilyen metakompetencia lehet például az intuíció. Azonban az irodalomban számos kérdés még nem tisztázott a kompetenciákkal kapcsolatban, illetve sok kompetenciamodell csak hagyományos munkakörelemzés, ami hibás kompetenciamérési feltételezés (Freudenberg, 2004). Az is kérdés például, hogy a kompetenciák tanultak-e vagy öröklöttek (Bakacsi, 1998), fejleszthetốk-e vagy nem. Mohácsi (1996) szerint a kompetenciák között különbséget tehetünk abban, hogy melyek öröklöttek, és melyek fejleszthetók, és abban is elkülönülnek, hogy milyen szinten fejleszthető́k. A tudásszint és a magatartásjellemzók a legkönnyebben taníthatók, míg az attitǔdök és az értékek a legkevésbé. Más szempontból viszont úgy is elkülöníthetjük a kompetenciákat, hogy azok „kemény” (például: szaktudás) vagy „puha” (például: empátia) kompetenciák-e (Meier, 2001). A kompetenciák azonban abból a szempontból is csoportosíthatók, hogy küszöbkompetenciák-e vagy sem (Mohácsi, 1996). A küszöbkompetenciák ezen elmélet szerint olyan nélkülözhetetlen személyiségjellemzók, amelyek hiányában az adott munkaköri feladatok minimálisan sem láthatók el. A mérleg másik végén azok a teljesítménykompetenciák állnak, amelyek megkülönböztetik a kiválóan teljesítóket az átlagosan teljesítóktől. A kompetenciák vizsgálata a vezetői munkakörök esetén előnyös a szervezet számára, illetve az egyén számára is, egyéni fejlődése és a kiváló teljesítmény elérése érdekében.

\section{A kiválóság területei}

Goleman (1998) részletesen taglalja a kiválóság területeit. Úgy gondolja, hogy a kiválóság területei az érzelmi kompetenciákhoz köthetốk. Olyan egyéni szocializációs folyamatok állnak ennek a hátterében, amelyek alakítják a személyiség meghatározó jegyeit. Minél összetettebb a munka, annál inkább számít az érzelmi intelligencia, mert annak hiánya hátráltató tényezó is egyben. A munkában való sikeresség szempontjából az értelmi intelligencián (kognitív képesség, IQ) alapuló értelmi kompetenciákra, gyakorlati kompetencián (szakértelem, tapasztalat, képesség vagy készségek tartoznak ide) alapuló gyakorlati kompetenciákra és az érzelmi intelligencián (kiváló teljesítményứ rendelkezik vele) alapuló érzelmi intelligenciákra egyaránt szükség van (Goleman, 1998). Az érzelmi kompetenciák kétszer olyan fontosak, mint a gyakorlati és kognitív kompetenciák. A vezetói pozíciókban pedig szinte csak az érzelmi kompetencia jelent előnyt a többiekkel szemben való versenyben. A hatékony és eredményes szervezet Goleman (1998) szerint a következóket várja el a munkatársaitól: a dolgozó legyen képes tanulni a munkájából, rendelkezzen figyelemmel és jó verbális kommunikációs készséggel, tudjon alkalmazkodni, legyen képes önmagát megszervezni (önbizalom, munkamotiváció, karrier iránti igény, büszkeség az elért 
eredményekre), csapat és személyközi hatékonyság jellemezze (kooperáció, csapatmunka, eltérő eredmények összehangolása) és hatékony szervezési és vezetối készségekkel bírjon. A vezetôi munkakörök esetén különösen érdemes odafigyelnie egy szervezetnek arra, hogy a nem hatékony vezetóket tovább fejlessze, illetve maguknak a vezetóknek is érdemes törődniük saját fejlődésükkel. Goleman (1998) szerint a rossz vezetôt a következók jellemezhetik: merev (rosszul reagál, nem tud másokat megérteni), szegényes kapcsolatokkal rendelkezik (keményen kritizál, túl sokat követel, érzéketlen, elidegenít mindenkit), az alkalmazkodás alacsony foka vagy hiánya jellemzi (alacsony empátiás készség és érzelmi önkontroll), az ilyen tulajdonságokkal rendelkező vezetô híján van az érzelmi kompetenciának.

\section{Az érzelmi intelligencia elméletei}

Goleman (1998) elméletével párhuzamosan ismerünk még olyan más csoportosítási rendszert is, amelyek mentén megkülönböztethetjük egymástól az érzelmi intelligencia modelljeit. Ezek közül az érzelmi intelligencia kevert modelljével (Mayer - Salovey - Caruso, 2000) foglalkozunk, mely elmélet egyik legismertebb képviselôje, Bar-On (1997: 17. o.) szerint az érzelmi intelligencia ,azon érzelmi, személyes és társas kompetenciák, valamint készségek együttese, amelyek hozzájárulnak ahhoz, hogy az egyén eredményesen küzdjön meg a környezete követelményeivel".

Bar-On (2004) szerint ,az érzelmi intelligencia és az érzelmi skillek fejlődnek az idôk során, változnak az élet folyamán, és fejleszthetốk mind tréninggel, mind terápiás technikákkal" (idézi: Takács, 2010: 40. o.). Bar-On (2004) érzelmiintelligencia-modelljében az EI arra a kérdésre adhat releváns választ: „Miért képes sikeresebbé válni néhány egyén az életben másoknál?" (Neubauer - Freudenthaler, 2005, idézi: Takács, 2010: 40. o.) Goleman és Bar-On az érzelmi intelligenciát a kompetenciakészlettel kapcsolja össze, így jelen tanulmány szempontjából ez az elmélet a releváns.

Ezért fontos minden vezető számára tisztában lenni saját érzelmiintelligencia-szintjével. A szervezeteknek pedig érdemes ennek a területnek a fokozott fejlesztésére idôt és energiát szakítaniuk.

\section{A vezetối kompetenciák}

London és Smither (1995) szerint a 360 -os visszajelzés igen népszerú szervezetfejlesztési technika, mely ugyan idő- és energiaigényes eszköz, a vezető́k sokat nyerhetnek ennek a módszernek az eredményéból. Visszajelzést kaphatnak több szinten is a saját értékelésük mel- lett, a beosztottaktól, a munkatársaktól, a felettesektól, és ha van rá lehetôség, a külsős partnertól is. Azonban a $360^{\circ}$-os visszajelzés érvényességéról keveset tudunk, mivel az értékelő csoportok gyakran teljesen máshogy értékelik a személyeket. Megfigyelhetô, hogy a vezetốk (a vezetô vezetôje) szignifikánsan alacsonyabbra értékelik a munkavállalókat (a vezetót), mint az azonos szinten dolgozó munkatársak, a beosztottak, vagy azok önmagukat (Atkins - Wood, 2002). Vagyis a vezetók (a vezetô vezetôje) sokkal kritikusabbak az értékelések alkalmával. Emellett az is megfigyelhetô, hogy a beosztottak és az azonos szinten dolgozó munkatársak adják a legmagasabb értékelést (Atkins - Wood, 2002). Carless és munkatársai (1998) ezzel szemben azt találták, hogy az önértékelés magasabb a beosztottak értékelésénél. Szerintük a felmért vezetốk az önértékelés alkalmával, saját védelmük érdekében, túlértékelték magukat, illetve szerintük a kor is nagyban befolyásolja azt, hogy ki, hogyan értékeli önmagát egy $360^{\circ}$-os visszajelzés alkalmával, mivel az idősebbek szignifikánsan túlértékelik önmagukat. Atkins és Wood (2002) eredményei szerint az értékelő csoportok eredményeinek sorrendje minden esetben a következó: a beosztottak értékeltek legmagasabbra, ezt követte az azonos szinten lévố munkatársak értékelése, az önértékelés, majd a vezetói értékelés a legalacsonyabb. Ezen elméletek különbségei miatt úgy gondolom, érdemes a $360^{\circ}$-os visszajelzést tovább vizsgálni. Hegyi (2012) szerint kapcsolat van a kompetenciamérések, a hagyományos pszichológiai mérések mérési tartományaival, vagyis kapcsolat lehet a vezetối kompetenciák mint $360^{\circ}$-os visszajelzés és a különböző pszichológiai tesztek eredményei között, mely kapcsolat segítheti a vezetô kompetenciaszintjének felmérését és a további pontosabb fejlesztését.

\section{A vizsgálat célja}

Feltérképezni a $360^{\circ}$-os visszajelzés önértékelés-öszszefüggéseit a kor, az érzelmi intelligencia és a személyiségjegyek függvényében. Jelen tanulmányban a $360^{\circ}$-os visszajelzés önértékelés-eredményei kerülnek tanulmányozásra, mivel az a kérdés, hogy a $360^{\circ}$-os visszajelzéssel kapcsolatos eredmények miért adnak ilyen nagy változatosságot a szakirodalomban, illetve a vezetói önértékelés e tényezók közül mely területeken mutat kapcsolatot?

\section{A vizsgálati személyek}

A Linamar Hungary Zrt. gyártósori csoportvezetói munkakör munkavállalói a vizsgálati személyek, akik egy pilot fejlesztési program keretében vettek részt a felmérésben. A Linamar Hungary Zrt. autóipari gépal- 
katrészeket gyártó multinacionális vállalat, magyarországi leányvállalata orosházi és békéscsabai telephelylyel múködik. A felmérésben 42 fő fett részt, átlagos életkoruk 35 év, szórás 8,1. 37 férfi és 5 nô, a vállalat profiljából adódóan inkább a férfi munkavállalók a dominánsak. A gyártósori csoportvezetô olyan személy, aki a gazdálkodó szervezetnél a termelési munka ellenôrzését és közvetlen irányítását végzi, általában ebben a munkakörben a vezetốk maguk a termelést végzôk közül kerülnek ki, ezért sokszor nem rendelkeznek a kellő vezetői készséggel, így fejlesztésük igen indokolt.

\section{Vizsgálati módszer}

\section{Bar-On-féle EQ-teszt}

Bar-On (1997) elgondolása alapján az érzelmi intelligencia 5 fő komponensre bontható. Egy intraperszonális skálára, egy interperszonális skálára, adaptációs skálára, stresszkezelés-skálára és általános hangulati skálára. Ezen belül pedig további 15 faktor található:

- intraperszonális érzelmi intelligencia: éntudatosság, önérvényesítés, önbecsülés, önmegvalósítás és függetlenség,

- interperszonális érzelmi intelligencia: empátia, interperszonális kapcsolatok és társas felelősségtudat,

- stresszkezeló érzelmi intelligencia: stressz-tolerancia és impulzuskontroll,

- alkalmazkodó érzelmi intelligencia: realitásérzék, rugalmasság és problémamegoldás,

- általános hangulati érzelmi intelligencia: optimizmus és boldogság.

A kérdőívek felvétele kis csoportban zajlott. A válaszok átlagolás alapján saját értékeikhez képest faktoronként alacsony és magas kategóriába lettek sorolva. Az eredményekrốl az összes teszt felvétele után kaptak egyéni visszajelzést a vezetők.

\section{Cattel 16 PF személyiségteszt}

A Cattel 16 PF (Cattell - Eber - Tatsuoka, 1970) kidolgozását két évtizedes faktoranalitikus kutatómunka előzte meg. Felnôttváltozata mellett serdülő és gyermekváltozatát is létrehozták. A jelenben elsôsorban kutatási és szúrési céllal alkalmazzák, bár a teszt körül a módszertani viták megfigyelhetôk, azonban úgy tûnik, hogy jól használható. Elsôsorban a munkapszichológia területén használatos, a laikusok számára is könnyen értelmezhetô. A Cattel 16 PF vizsgált faktorai a következók:

1. tartózkodó-szívélyes,

2. konkrét gondolkodású-absztrakt gondolkodású,

3. érzelmileg stabil-érzelmileg labilis,

4. domináns-alárendelődő,

5. komoly-eleven,

6. szabálykövető-szabályok alól kibúvó,
7. félénk-bátor,

8. számító-érzelmi beállítottságú,

9. bizalomteli-gyanakvó,

10. praktikus-fantáziadús,

11. egyenes-titkolózó,

12. magabiztos-aggódó,

13. hagyományszerető-kísérletező,

14. csoportember-önálló,

15. hibatûrô-perfekcionista,

16. nyugodt-feszült.

A kérdőív felvétele kis csoportban zajlott. Az eredményekrôl az összes teszt felvételét követően kaptak egyéni visszajelzést a vezetôk.

\section{A $360^{\circ}$-os visszajelzés}

A $360^{\circ}$-os visszajelzés esetén általában 6 értékelő csoport ad visszajelzést ugyanazon szempontok alapján a vezetőról. Értékeli önmaga, a vezetője, a beosztottja, az azonos szinten dolgozó munkatársa, és ha van rá lehetőség, egy külső értékelő is, például ez értékesítői pozíciók esetén lehet ez hasznos. A teszt felvétele a középvezetók tájékoztatását követôen történt. A középvezetók maguk adták meg azoknak a felső vezetóknek, munkatársaknak és beosztottaknak a neveit, akikról úgy gondolták, hogy ismerik annyira a munkájukat, hogy értékelni tudják ôket. Ezek közül az értékelő jelöltek közül random került kiválasztásra 2 fő felső vezető, 2 fő azonos szinten dolgozó munkatárs és 2 fő beosztott, akik az értékelést elvégezték. A külső értékelő választására nem volt lehetőség, mert a csoportvezetôk nem állnak ilyen partnerrel kapcsolatban. Jelen tanulmány szempontjából a $360^{\circ}$-os visszajelzés önértékelése az érdekes, de fontosnak tartottam bemutatni az értékelési rendszert is, melybe ágyazva található az önértékelés. A vizsgált vezetôi kompetenciákat egy 1-4-ig terjedő skálán véleményezték az értékelők, 1=egyáltalán nem jellemző, 2=nem jellemző, $3=$ jellemzó, 4=teljes mértékben jellemzô. Az eredmények elemzésénél gyenge és jó kategóriába lettek csoportosítva a válaszok, a gyenge kategóriába kerültek az 1-es és a 2-es válaszok, a jó kategóriát alkották a 3-as és a 4-es értékek. Így a megfogalmazások értelmében, ha 1-es vagy 2 -es választ adtak az értékelők, akkor a kompetenciaelem tudása nem vagy gyenge szinten jelentkezett csak, ha 3-as vagy 4-esre értékeltek a jelöltek, akkor pedig jó vagy kiváló teljesítményt mutatott a kompetenciaelem. A kiválasztott, a munkakör szempontjából fontos kompetenciák a következók voltak: konfliktuskezelés, együttmúködés, meggyőzés, problémamegoldás, döntésképesség, ellenőrzés, felelősségvállalás, szorgalom, precizitás és teljesítménymenedzsment. A kompetencia megfogalmazásokat az 1. táblázat foglalja össze, a $360^{\circ}$-os visszajelzés kérdőív 


\section{A $360^{\circ}$-os visszajelzésen vizsgált kompetenciák és fogalmak meghatározásai}

Döntésképesség: Az egyén időben és a következményeket vállalva képes meghozni a reálisnak tekinthetô döntést.

Együttmúködés: Az egyén képes munkatársaival, beosztottjaival, a szervezet céljainak elérése érdekében hatékonyan, előremutatóan együtt dolgozni.

Konfliktuskezelés: Az egyén képes a problémás, konfliktusos helyzetek okait nyíltan, konstruktívan feltárni, és igyekszik megelőzni a konfliktusos helyzetek kialakulását. Ha mégis kialakul a konfliktus, nyertes-nyertes szituáció kialakítására törekszik. Közvetító szerepet vállal mások konfliktusainak megoldásában.

Meggyózés: A vezető a vállalat alapértékeinek megfelelóen képes elérni, hogy az irányítása alatt álló csoportban dolgozók magukénak érezzék a vállalat jövőképét, és aktívan, felelősségteljesen tevékenykednek a célok elérése érdekében.

Problémamegoldás: Az egyén képes a problémát azonosítani, részletekre bontani, a részek közötti összefüggéseket, ok-okozati kapcsolatokat meghatározni, feltárni, a rendelkezésre álló megoldási lehetôségeket végiggondolni, számba venni, és közülük a cél elérését, azaz a probléma megoldását, a legjobban megvalósító változatot kiválasztani.

Ellenórzés: Az egyén képes a felelôsségi körébe tartozó folyamatokról, az irányítása alatt álló emberekról, olyan módon információt gyújteni, amely lehetôvé teszi azt, hogy a feladatokat, a folyamatokat kontroll alatt tartsa. Az ellenôrzés eredménye, a tények megállapítása, melyek alapján további intézkedéseket tehet.

Feleloosségvállalás: Az egyén képes felelôsségteljesen elvégezni a rábízott feladatokat, vállalja saját cselekedeteinek következményeit, és tudatában van az adott munka végeredményéhez való személyes hozzájárulás fontosságával. Feladatait következetesen látja el. A munka során rendelkezésre áll, mindig lehet rá számítani. Munkavégzésére az elvárható és sajátjának is vallott erkölcsi, etikai normáknak megfelelő viselkedés a jellemzô.

Szorgalom: Az egyén munkaidejét teljes mértékben hatékonyan és eredményesen kihasználja munkavégzésre, aktív, keresi az új kihívásokat, vállalja a többletmunkával járó feladatokat is. Újító, csapatának munkáját úgy szervezi, hogy az a lehető leghatékonyabb legyen.

Precizitás: Az egyén törekszik a közel hibátlan, elvárásoknak megfelelő munkavégzésre. A folyamatok, szabályok alapos betartására. Betartja a határidóket, és van érzéke a részletekhez, képes az általa irányított csoportban is megteremteni ezeket az értékeket, igényes a saját munkavégzésére.

Teljesítménymenedzsment: Az egyén képes a rendelkezésére álló információk alapján, objektíven és az összehasonlítási kritériumoknak megfelelően értékelni az irányítása alatt álló dolgozókat, és errôl a dolgozónak fejlesztő és motiváló visszajelzést adni. Képes a célok elérése érdekében a saját tapasztalatait, tudását felhasználva a rábízott munkavállalókat fejleszteni.

kompetenciáinak megbízhatósági vizsgálata egy elôzetes tanulmány témája volt, de a kompetenciák minden esetben megfelelnek a megbízhatóság kritériumainak.

\section{Statisztika}

A Cattel 16 PF, a Bar-On-féle EQ-teszt és a $360^{\circ}$-os visszajelzés eredményeinek összehasonlítására egy szempontos ANOVA-t alkalmaztam, szignifikanciaszint $p<0,05$. A tesztek és a $360^{\circ}$-os visszajelzés értékeléseinek összehasonlítására Khínégyzet próbát, Pearson-féle korrelációs módszert pedig a tesztek és a $360^{\circ}$-os visszajelzés értékeló csoportok eredményeinek vizsgálatára alkalmaztam.

\section{Eredmények}

\section{Az életkori különbségek és a $360^{\circ}$-os visszajelzés vizsgálata kompetenciánként}

Az átlagos életkor 36 év (szórás 8). A vezetôi kompetenciákban és az életkorban nincs szignifikáns öszszefüggés $(F(1)=2,7, p>0,05)$. A kompetenciák külön elemzésénél, az együttmúködés kompetencia esetén az önmaguk szerint gyengén együttmúködőek az idősebb korosztály tagjai, az önmaguk szerint jól együttmúködőek a fiatalabb korosztály tagjai $(F(1)=6,7, p<0,05)$, az összefüggés szignifikáns. További kompetenciák esetén nincs szignifikáns különbség az életkor alapján (döntésképesség: $\mathrm{F}(1)=0,36, \mathrm{p}>0,05$; konfliktuskezelés: $\mathrm{F}(1)=1,8, \mathrm{p}>0,05$; meggyőzés: $\mathrm{F}(1)=0,2, \mathrm{p}>0,05$; problémamegoldás: $F(1)=0,36, p>0,05$; ellenórzés: $F(1)=1,2$, $p>0,05$; felelősségvállalás: $F(1)=1,7, p>0,05$; precizitás: $F(1)=1,08, p>0,05$; szorgalom: $F(1)=1,1, p>0,05$; teljesítménymenedzsment: $\mathrm{F}(1)=0,006, \mathrm{p}>0,05)$.

\section{Az EQ-teszt és a $360^{\circ}$-os visszajelzés-önértékelés kapcsolata kompetenciánként}

A két teszt közepes korrelációt mutat $(\mathrm{r}=0,524$, $\mathrm{p}<0,05)$, vagyis azt mondhatjuk, hogy a $360^{\circ}$-os viszszajelzés-önértékelés eredményének kapcsolata van az érzelmi intelligencia szintjével. A döntésképesség kompetencia esetén a legtöbb önmaga szerint jó döntésképességgel rendelkező vezető magas EQ-pontszámot ért el $(F(1)=3,4, p>0,05$, tendenciaszintú kapcsolat). Együttmúködés esetén szintén ez az eredmény született,

\section{VEZETÉSTUDOMÁNY}


aki jól teljesít az önbevallása szerint az együttmúködés területén, az magasabb EQ-pontszámot ért el, azonban az eredmény nem szignifikáns $(F(1)=0,06, p>0,05)$. A konfliktuskezelés és az önértékelés szignifikáns kapcsolatot mutat, azok, akik jól kezelik a konfliktusokat önbevallásuk alapján, azoknak magas az érzelmiintelligencia-pontszáma $(F(1)=8,5, p<0,05)$, és a további kompetenciák esetén is kimutatható ez a szignifikáns kapcsolat: meggyőzés $(F(1)=6,79, p<0,05$; problémamegoldás $(\mathrm{F}(1)=9,8, \mathrm{p}<0,05$; ellenőrzés $(\mathrm{F}(1)=4,9, \mathrm{p}<0,05$; felelősségvállalás $(\mathrm{F}(1)=5,2, \mathrm{p}<0,05$; precizitás $(\mathrm{F}(1)=7$, $\mathrm{p}<0,05$; szorgalom $(\mathrm{F}(1)=8,8, \mathrm{p}<0,05$; teljesítménymenedzsment $(\mathrm{F}(1)=6,7, \mathrm{p}<0,05,2$. táblázat $)$. Vagyis azok, akik magas EQ-pontszámot értek el, azok magasra értékelték önmagukat a kompetenciák esetén is.

\section{EQ intraperszonális skála és a $360^{\circ}$-os visszajelzés önértékelés kapcsolata kompetenciánként}

Teljesítménymenedzsment-kompetencia esetén, akik önmagukat magasan értékelték, vagyis önbevallásuk szerint a teljesítménymenedzsment-feladatot jól ellátják, azok magas EQ-pontszámot értek el az intraperszonális skálán $(\mathrm{F}(1)=6,6, \mathrm{p}<0,05,2$. táblázat $)$. A precizitás $(\mathrm{F}(1)=6,7, \mathrm{p}<0,05,2$. táblázat $)$, a szorgalom $(\mathrm{F}(1)=16,1, \mathrm{p}<0,01,2$. táblázat $)$, a konfliktuskezelés $(\mathrm{F}(1)=5,4, \mathrm{p}<0,05,2$. táblázat) és a problémamegoldás $(\mathrm{F}(1)=8,7, \mathrm{p}<0,05,2$. táblázat) esetén azok, akik az EQ intraperszonális skálán magas pontszámot értek el, azok jellemzóen magasra értékelték magukat, akik alacsony pontszámot értek el, azok gyengére értékelték önmagukat is. Meggyőzés kompetencia esetén, akik magasra értékelték önmagukat az EQ intraperszonális skálán is magas pontot értek el, azonban, akik alacsonyra értékelték önmagukat, azok is jellemzóen magas pontszámot értek el az érzelmiintelligencia-teszt e skáláján $(\mathrm{F}(1)=4,1, \mathrm{p}<0,05,2$. táblázat $)$. A meggyôzés vezetôi kompetencia esetén további vizsgálatokra van szükség az érzelmi intelligencia intraperszonális skálájával összefüggésben. A további kompetenciák esetén nincs szignifikáns kapcsolat a tesztek eredményei között (döntésképesség: $(F(1)=1,99, p>0,05$; együttmúködés: $F(1)=0,5, p>0,05$; ellenőrzés: $F(1)=2,4, p>0,05$; felelősségvállalás: $F(1)=2,3, p>0,05)$.

EQ interperszonális skála és a $360^{\circ}$-os visszajelzésönértékelés kapcsolata kompetenciánként

A döntésképesség $(\mathrm{F}(1)=4,9, \mathrm{p}<0,05,2$. táblázat) és a felelósségvállalás $(F(1)=6,3, p<0,05,2$. táblázat) kompetencia esetén szignifikáns az összefüggés az érzelmiintelligencia-teszt interperszonális skálája és a $360^{\circ}$-os visszajelzés önértékelése között. Azok, akik magas pontszámot értek el ezen a skálán, azok jellem- zően magasra értékelték önmagukat a vezetôi kompetenciák esetén. A konfliktuskezelés $(F(1)=3,4, p<0,05)$ és a teljesítménymenedzsment $(\mathrm{F}(1)=3,7, \mathrm{p}<0,05)$ kompetencia esetén pedig tendenciaszintú az összefüggés, azok, akik alacsony EQ-pontszámot értek el, alacsonyra értékelték önmagukat is ezekben a kompetenciákban. A további, vizsgált vezetôi kompetenciák esetén szignifikáns összefüggés nem mutatható ki (együttmúködés: $(\mathrm{F}(1)=2,5, \mathrm{p}>0,05$; meggyőzés: $\mathrm{F}(1)=0,8$, $\mathrm{p}>0,05$; problémamegoldás: $\mathrm{F}(1)=1,2, \mathrm{p}>0,05$; ellenốrzés: $\mathrm{F}(1)=2,1, \mathrm{p}>0,05$; precizitás: $\mathrm{F}(1)=1,2, \mathrm{p}>0,05$; szorgalom: $F(1)=0,1, p>0,05)$.

EQ adaptációs skála és a $360^{\circ}$-os visszajelzés-önértékelés kapcsolata kompetenciánként

A teljesítménymenedzsment $(\mathrm{F}(1)=7,29, \mathrm{p}<0,05,2$. táblázat) és a problémamegoldás $(\mathrm{F}(19=4,4, \mathrm{p}<0,05,2$. táblázat) kompetencia esetén szignifikáns a kapcsolat az adaptációs skála eredményeivel. Tendenciaszintú az összefüggés a döntésképesség $(\mathrm{F}(1)=3,6, \mathrm{p}>0,05)$, a meggyőzés $(\mathrm{F}(1)=3,7, \mathrm{p}>0,05)$ és a felelősségvállalás $(\mathrm{F}(1)=3,3, \mathrm{p}>0,05)$ esetén. Jellemzóen az eddig említett kompetenciák esetén megfigyelhető, hogy azok, akik magasra értékelték önmagukat a kérdések alapján, magas pontszámot értek el az adaptációs skálán is. A további kompetenciák esetén nincs szignifikáns összefüggés a skálával (együttmúködés: $\mathrm{F}(1)=0,79$, $\mathrm{p}>0,05$; konfliktuskezelés: $\mathrm{F}(1)=1,8, \mathrm{p}>0,05$; ellenőrzés: $\mathrm{F}(1)=2$, $p>0,05$; precizitás: $\mathrm{F}(1)=2,3$, $\mathrm{p}>0,05$; szorgalom: $\mathrm{F}(1)=2,2, \mathrm{p}>0,05)$.

\section{Az EQ stresszkezelés-skála és a $360^{\circ}$-os visszajel- zés-önértékelés kapcsolata kompetenciánként}

A teljesítménymenedzsment esetén szignifikáns az összefüggés a $360^{\circ}$-os visszajelzés önértékelésének eredményével $(\mathrm{F}(1)=9,5, \mathrm{p}<0,05$, 2. táblázat $)$. Azonban az eredmények megoszlanak, azok, akik magas pontszámot értek el, magasra értékelték magukat, viszont majdnem ugyanennyien alacsonyra értékelték magukat a jól teljesítók között, ami egy érdekes összefüggés, és további kérdéseket vethet fel. A meggyőzés $(\mathrm{F}(1)=3,3$, $\mathrm{p}>0,05)$ és az ellenórzés $(\mathrm{F}(1)=3,3, \mathrm{p}>0,05)$ kompetencia esetén tendenciaszintú összefüggés mutatható ki. Jellemzóen az említett kompetenciák esetén megfigyelhetô, hogy azok, akik magasra értékelték önmagukat, magas pontszámot értek el a stresszkezelés-skálán is. Nincs szignifikáns összefüggés a további kompetenciák esetén (döntésképesség: $\mathrm{F}(1)=1,39, \mathrm{p}>0,05$; együttmúködés: $F(1)=0,7, p>0,05$; konfliktuskezelés: $F(1)=0,88$, $p>0,05$; problémamegoldás: $F(1)=2, p>0,05$; felelősségvállalás: $F(1)=1,7, p>0,05$; precizitás: $F(1)=0,23$, $p>0,05$; szorgalom: $F(1)=0,84, p>0,05)$. 
Az EQ általános hangulati skála és a $360^{\circ}$-os visszajelzésönértékelés-kapcsolata kompetenciánként

A konfliktuskezelés $(\mathrm{F}(1)=4,6, \mathrm{p}<0,05,2$. táblázat $)$, a problémamegoldás $(\mathrm{F}(1)=8,7, \mathrm{p}<0,05,2$. táblázat $)$ és a teljesítménymenedzsment $(\mathrm{F}(1)=5,4, \mathrm{p}<0,05,2$. táblázat $)$ kompetenciák és a hangulati skála között is szignifikáns az összefüggés a $360^{\circ}$-os visszajelzés eredményeivel. Az említett kompetenciák esetén megfigyelhetô, hogy azok, akik magasra értékelték önmagukat a kérdések alapján, magas pontszámot értek el az általános hangulati skálán is. Tendenciaszintú az összefüggés a precizitás $(F(1)=3$, $\mathrm{p}>0,05$ ) és az általános hangulati skálával. Nincs szignifikáns kapcsolat a további kompetenciák esetén (döntésképesség: $\mathrm{F}(1)=1,1, \mathrm{p}>0,05$; együttmúködés: $\mathrm{F}(1)=0,7$, $p>0,05$; meggyőzés: $F(1)=1,4, \quad p>0,05$; ellenőrzés: $(\mathrm{F}(1)=2,4, \mathrm{p}>0,05$; felelősségvállalás: $\mathrm{F}(1)=2,7, \mathrm{p}>0,05$; szorgalom: $\mathrm{F}(1)=2,1, \mathrm{p}>0,05)$.

\section{A $360^{\circ}$-os visszajelzés-önértékelés és a Cattel 16 PF teszt kapcsolata}

A Cattel 16 PF személyiségteszt tendenciaszintú gyenge korrelációt mutat a vezetôi kompetenciákkal (összes kompetencia esetén, r=0,312, p>0,05). Három faktorral van szignifikáns kapcsolata a $360^{\circ}$-os visszajelzés önértékelés összpontszámának: a komoly-eleven faktorral $(\mathrm{F}(1)=5,8, \mathrm{p}<0,05$, 3. táblázat $)$; a félénk-bátor faktorral $(\mathrm{F}(1)=4,7, \mathrm{p}<0,05,3$. táblázat $)$ és a hagyományszerető-kísérletező faktorral $(\mathrm{F}(1)=6,6, \mathrm{p}<0,05$, 3. táblázat). A komoly-eleven és a félénk-bátor faktor esetén, ha valaki magasra értékeli önmagát a kompetenciák esetén, arra jellemző az elevenség és a bátorság, aki viszont alacsonyra értékeli önmagát, az komoly és félénk. A hagyományszeretốkísérletező faktor esetén megoszlanak a válaszok, azok, akik alacsonyra értékelik magukat, azok inkább hagyományszeretốk. Ha valaki kísérletezô, az esetben nem figyelhetô meg, hogy magas lenne az önértékelése is, mert a válaszok megoszlanak, az alacsony és a magas értékelés között. A többi faktor esetén nem mutatható ki szignifikáns kapcsolat a $360^{\circ}$-os visszajelzés eredményeivel (tartózkodó-szívélyes $(\mathrm{F}(1)=1,8, \mathrm{p}>0,05$; konkrét gondolkodású-absztrakt gondolkodású: $\mathrm{F}(1)=0,22$, $\mathrm{p}>0,05$; túlérzékeny-érzelmileg stabil: $\mathrm{F}(1)=0,42$, $\mathrm{p}>0,05$; önalávetó-uralkodó: $\mathrm{F}(1)=0,16, \mathrm{p}>0,05$; szabálykövetô-szabályok alól kibúvó: $F(1)=0,74, p>0,05$; számító-érzelmi beállítottságú: $\mathrm{F}(1)=1,18, \mathrm{p}>0,05$; bizalomteli-gyanakvó: $\mathrm{F}(1)=0,43, \quad \mathrm{p}>0,05$; praktikus-fantáziadús: $\mathrm{F}(1)=1,5, \mathrm{p}>0,05$; egyenes-titkolózó: $F(1)=0,18, p>0,05$; magabiztos-aggódó: $F(1)=2,5$, $\mathrm{p}>0,05 ;$ hagyományszeretô-kísérletezó: $\mathrm{F}(1)=0,15$, $\mathrm{p}>0,05$; hibatứő- perfekcionista: $\mathrm{F}(1)=0,39, \mathrm{p}>0,05$; nyugodt-feszült: $F(1)=0,39, p>0,05)$.
A $360^{\circ}$-os visszajelzés-döntésképesség és a Cattel 16 PF faktorok kapcsolata

A döntésképesség kompetencia önértékelése esetén a szabálykövető - szabályok alól kibúvó - faktor eredményével mutat a teszt tendenciaszintú összefüggést $(\mathrm{F}(1)=2,9, \mathrm{p}>0,05)$. A többi faktor esetén nincs szignifikáns kapcsolat (tartózkodó-szívélyes: $\mathrm{F}(1)=0,27$, $\mathrm{p}>0,05$; konkrét gondolkodású-absztrakt gondolkodású: $\mathrm{F}(1)=0,97, \mathrm{p}>0,05$; érzelmileg stabil-érzelmileg labilis: $\mathrm{F}(1)=0,002, \quad \mathrm{p}>0,05$; domináns-alárendelődô: $F(1)=0,119, p>0,05$; komoly-eleven: $F(1)=0,174$, $\mathrm{p}>0,05$; félénk-bátor: $\mathrm{F}(1)=1,007, \mathrm{p}>0,05$; számítóérzelmi beállítottságú: $\mathrm{F}(1)=2,1, \mathrm{p}>0,05$; bizalomteligyanakvó: $\mathrm{F}(1)=0,009, \quad \mathrm{p}>0,05$; praktikus-fantáziadús: $F(1)=0,84, p>0,05$; egyenes-titkolózó: $F(1)=0,63$ $p>0,05 ;$ magabiztos-aggódó: $F(1)=0,004, \quad p>0,05$; hagyományszerető-kísérletezó: $\quad \mathrm{F}(1)=0,05, \quad \mathrm{p}>0,05$; csoportember-önálló: $\mathrm{F}(1)=0,01, \quad \mathrm{p}>0,05$; hibatû́ôperfekcionista: $F(1)=0,74, p>0,05$; nyugodt-feszült: $F(1)=0,53, p>0,05)$.

\section{A $360^{\circ}$-os visszajelzés-együttmúködés és a Cattel} 16 PF faktorok kapcsolata

Együttmúködés kompetencia önértékelés esetén a félénk-bátor faktor esetén $(F(1)=2,98, p>0,05)$ és a tartózkodó-szívélyes faktor esetén $(\mathrm{F}(1)=3,1, \mathrm{p}>0,05)$ tendenciaszintú az összefüggés az eredmények alapján. A többi faktor esetén nincs szignifikáns kapcsolat (konkrét gondolkodású-absztrakt gondolkodású: $F(1)=0,86, p>0,05$; érzelmileg stabil-érzelmileg labilis: $\mathrm{F}(1)=2,63, \mathrm{p}>0,05$; domináns-alárendelődő: $\mathrm{F}(1)=1,52, \mathrm{p}>0,05$; komolyeleven: $F(1)=0,204, p>0,05$; szabálykövető-szabályok alól kibúvó: $\mathrm{F}(1)=1,08, \mathrm{p}>0,05$; számító-érzelmi beállítottságú: $\mathrm{F}(1)=0,08, \quad \mathrm{p}>0,05$; bizalomteli-gyanakvó: $\mathrm{F}(1)=0,05, p>0,05$; praktikus-fantáziadús: $\mathrm{F}(1)=0,30$, $p>0,05$; egyenes-titkolózó: $F(1)=0,59, p>0,05$; magabiztos-aggódó: $\mathrm{F}(1)=0,41, \mathrm{p}>0,05$; hagyományszeretókísérletezó: $\mathrm{F}(1)=0,65, \mathrm{p}>0,05$; csoportember-önálló: $\mathrm{F}(1)=0,07, \mathrm{p}>0,05$; hibatürö-perfekcionista: $\mathrm{F}(1)=0,70$, $\mathrm{p}>0,05$; nyugodt-feszült: $\mathrm{F}(1)=0,04, \mathrm{p}>0,05)$.

\section{A $360^{\circ}$-os visszajelzés-konfliktuskezelés kompeten- cia és a Cattel 16 PF faktorok kapcsolata}

Konfliktuskezelés kompetencia önértékelés esetén szignifikáns a kapcsolat a félénk-bátor faktor esetén ( $\mathrm{F}(1) 4,3, \mathrm{p}<0,05$, 3. táblázat), a bizalomteli-gyanakvó faktor esetén $(\mathrm{F}(1)=4,9, \mathrm{p}<0,05,3$. táblázat $)$ és a nyugodt-feszült faktor esetén $(\mathrm{F}(1)=5,3, \mathrm{p}<0,05,3$. táblázat). Azok, akik magasra értékelték önmagukat a konfliktuskezelés esetén, jellemzően bátrak, azok, akik pedig alacsonyra, jellemzően félénkek. Azonban azok a személyek, akik alacsonyra értékelték önmagukat a 
konfliktuskezelés területén, azok gyanakvóak, akik pedig magasra, azok bizalommal telik, illetve akik alacsonyra értékelték magukat, azok feszültek, akik pedig magasra, azok a személyek nyugodtak. Tendenciaszintû a kapcsolat az érzelmi stabilitás-érzelmi labilitás faktor esetén $(\mathrm{F}(1)=4,06, \mathrm{p}>0,05)$ és a hagyományszeretőkísérletező $(\mathrm{F}(1)=2,8, \mathrm{p}<0,05)$ faktor esetén is. A többi faktor esetén nincs szignifikáns kapcsolat (tartózkodó-szívélyes: $\mathrm{F}(1)=0,43$, p>0,05; konkrét gondolkodású-absztrakt gondolkodású: $\mathrm{F}(1)=0,01, \mathrm{p}>0,05$; domináns-alárendelődő: $F(1)=3,26, p>0,05$; komoly-eleven: $\mathrm{F}(1)=1,4, \mathrm{p}>0,05$; szabálykövetô-szabályok alól kibúvó: $(\mathrm{F}(1)=1,08, \mathrm{p}>0,05$; számító-érzelmi beállítottságú: $\mathrm{F}(1)=2,4, \mathrm{p}>0,05$; praktikus-fantáziadús: $\mathrm{F}(1)=0,02$, p>0,05; egyenes-titkolózó: $\mathrm{F}(1)=0,73$ p>0,05; magabiztos-aggódó: $\mathrm{F}(1)=1,70, \mathrm{p}>0,05$; csoportemberönálló: $\mathrm{F}(1)=039$, $\mathrm{p}>0,05$; hibatưrô-perfekcionista: $\mathrm{F}(1)=0,17, \mathrm{p}>0,05)$.

\section{$A 360^{\circ}$-os visszajelzés-meggyózés kompetencia és a Cattel 16 PF faktorok kapcsolata}

Meggyőzés kompetencia önértékelése esetén egy faktor esetén sincs szignifikáns kapcsolat a Cattel 16 PF faktorokkal (tartózkodó-szívélyes: $F(1)=0,20, p>0,05$; konkrét gondolkodású-absztrakt gondolkodású: $\mathrm{F}(1)=0,260, \mathrm{p}>0,05$; érzelmi stabilitás-érzelmi labilitás $\mathrm{F}(1)=1,1, \mathrm{p}>0,05$; domináns-alárendelődô: $\mathrm{F}(1)=1,08$, p $>0,05$; komoly-eleven: $\mathrm{F}(1)=0,28, \mathrm{p}>0,05$; szabálykövető-szabályok alól kibúvó: $(\mathrm{F}(1)=2,33, \mathrm{p}>0,05$; félénk-bátor $\mathrm{F}(1)=0,22$, p>0,05; számító-érzelmi beállítottságú: $\mathrm{F}(1)=1,56, \mathrm{p}>0,05$; bizalomteli-gyanakvó $(\mathrm{F}(1)=2,09, \mathrm{p}>0,05$; praktikus-fantáziadús: $\mathrm{F}(1)=1,15$, p>0,05; egyenes-titkolózó: $\mathrm{F}(1)=0,61$ p $>0,05$; magabiztos-aggódó: $\mathrm{F}(1)=0,87, \mathrm{p}>0,05$; hagyományszeretőkísérletező: $\mathrm{F}(1)=2,50, \mathrm{p}>0,05$; csoportember-önálló: $\mathrm{F}(1)=1,20, \mathrm{p}>0,05$; hibatưrő-perfekcionista: $\mathrm{F}(1)=0,42$, $\mathrm{p}>0,05$; nyugodt-feszült: $\mathrm{F}(1)=1,17, \mathrm{p}>0,05)$.

A $360^{\circ}$-os visszajelzés-problémamegoldás kompetencia és a Cattel 16 PF faktorok kapcsolata

Problémamegoldás kompetencia önértékelés esetén szignifikáns a kapcsolat az egyenes-titkolózó faktorral $(\mathrm{F}(1)=4,08, \mathrm{p}<0,05,3$. táblázat $)$. Az eredmények azonban megoszlanak, a vezetók jellemzóen magas pontszámot értek el a Cattel 16 PF teszt e faktorán, vagyis inkább titkolózóak, az önértékelés a problémamegoldás területén pedig jellemzően alacsonyra értékelték önmagukat. Tendenciaszintú az összefüggés a számító-érzelmi beállítottság faktor esetén $(F(1)=2,98, p>0,05)$ és a hagyományszerető-kísérletező $(\mathrm{F}(1)=2,86, \mathrm{p}>0,05)$ faktor esetén. A többi faktorban nincs szignifikáns kapcsolat (tartózkodó-szívélyes: $F(1)=0,22$, p>0,05; konk- rét gondolkodású-absztrakt gondolkodású: $\mathrm{F}(1)=0,13$ $\mathrm{p}>0,05$; érzelmi stabilitás-érzelmi labilitás $\mathrm{F}(1)=0,12$, $\mathrm{p}>0,05$; domináns-alárendelődő: $\mathrm{F}(1)=2,5, \mathrm{p}>0,05$; komoly-eleven: $\mathrm{F}(1)=1,38, \mathrm{p}>0,05$; szabálykövető-szabályok alól kibúvó: $(\mathrm{F}(1)=0,03, \mathrm{p}>0,05$; félénk-bátor: $(\mathrm{F}(1)=2,31, \mathrm{p}>0,05$; bizalomteli-gyanakvó: $(\mathrm{F}(1)=0,16$, p $>0,05$; praktikus-fantáziadús: $\mathrm{F}(1)=0,21$, p $>0,05$; magabiztos-aggódó: $\mathrm{F}(1)=0,12$, p $>0,05$; csoportemberönálló: $\mathrm{F}(1)=0,36, \mathrm{p}>0,05$; hibatúrő-perfekcionista: $\mathrm{F}(1)=1,88, \quad \mathrm{p}>0,05 ; \quad$ nyugodt-feszült: $\quad \mathrm{F}(1)=0,17$, $\mathrm{p}>0,05)$.

\section{A $360^{\circ}$-os visszajelzés-ellenôrzés kompetencia és a Cattel 16 PF faktorok kapcsolata}

Ellenőrzés kompetencia önértékelés esetén egy faktorral sincs szignifikáns kapcsolat a Cattel 16 PF tesztnek (tartózkodó-szívélyes: $\mathrm{F}(1)=0,26$, p>0,05; konkrét gondolkodású-absztrakt gondolkodású: $\mathrm{F}(1)=0,509$, p $>0,05$; érzelmi stabilitás-érzelmi labilitás: $\mathrm{F}(1)=0,289$, p $>0,05$; domináns-alárendelődő: $\mathrm{F}(1)=0,018$ p $>0,05$; komoly-eleven: $\mathrm{F}(1)=0,66 \mathrm{p}>0,05$; szabálykövetôszabályok alól kibúvó: $(\mathrm{F}(1)=0,306, \mathrm{p}>0,05$; félénkbátor $(\mathrm{F}(1)=0,14, \quad \mathrm{p}>0,05$; számító-érzelmi beállítottságú: $\mathrm{F}(1)=0,047, \mathrm{p}>0,05$; bizalomteli-gyanakvó: $(\mathrm{F}(1)=0,11, \mathrm{p}>0,05$; praktikus-fantáziadús: $\mathrm{F}(1)=0,40$, p $>0,05$; egyenes-titkolózó: $F(1)=0,25$ p $>0,05$; magabiztos-aggódó: $\mathrm{F}(1)=1,06, \mathrm{p}>0,05$; hagyományszeretőkísérletezô: $\mathrm{F}(1)=3,65, \mathrm{p}>0,05$; csoportember-önálló: $F(1)=0,67, p>0,05$; hibatûrő-perfekcionista: $F(1)=0,17$, $\mathrm{p}>0,05$; nyugodt-feszült: $\mathrm{F}(1)=2,16, \mathrm{p}>0,05)$.

\section{A 360 -os visszajelzés-felelösségvállalás kompeten- cia és a Cattel 16 PF faktorok kapcsolata}

Felelősségvállalás kompetencia önértékelés esetén szignifikáns a kapcsolat a félénk-bátor faktor esetén $(\mathrm{F}(1)=4,7, \mathrm{p}<0,05,3$. táblázat $)$. Azok, akik magasra értékelték önmagukat felelősségvállalás területén inkább bátrak, akik pedig alacsonyra, azok félénkek. Tendenciaszintú az összefüggés a hagyományszerető-kísérletező faktor esetén $(F(1)=3,2$, p>0,05). A többi faktor esetén nincs szignifikáns kapcsolat (tartózkodó-szívélyes: $\mathrm{F}(1)=0,38, \quad \mathrm{p}>0,05$; konkrét gondolkodású-absztrakt gondolkodású: $\mathrm{F}(1)=0,93, \mathrm{p}>0,05$; érzelmi stabilitásérzelmi labilitás: $\mathrm{F}(1)=1,13, \mathrm{p}>0,05$; domináns-alárendelődő: $\mathrm{F}(1)=0,40, \mathrm{p}>0,05$; komoly-eleven: $\mathrm{F}(1)=0,53$, p>0,05; szabálykövetô-szabályok alól kibúvó: $\mathrm{F}(1)=0,14, \mathrm{p}>0,05$; félénk-bátor: $(\mathrm{F}(1)=0,83, \mathrm{p}>0,05$; bizalomteli-gyanakvó: $\mathrm{F}(1)=1,21, \mathrm{p}>0,05$; praktikusfantáziadús: $\mathrm{F}(1)=2,77, \mathrm{p}>0,05$; magabiztos-aggódó: $\mathrm{F}(1)=0,83, \mathrm{p}>0,05$; csoportember-önálló: $\mathrm{F}(1)=0,90$, $\mathrm{p}>0,05$; hibatúrô-perfekcionista: $\mathrm{F}(1)=0,008, \mathrm{p}>0,05$; nyugodt-feszült: $F(1)=2,4, p>0,05)$. 


\section{A $360^{\circ}$-os visszajelzés precizitás kompetencia és a Cattel 16 PF faktorok kapcsolata}

Precizitás kompetencia önértékelés esetén szignifikáns a kapcsolat a komoly-eleven faktorral $(\mathrm{F}(1)=5,4$, $\mathrm{p}<0,05)$ és a magabiztos-aggódó faktorral $(\mathrm{F}(1)=4,5$, $\mathrm{p}<0,05$, 3. táblázat). Ha valaki a precizitás területén önmagának alacsony pontszámot adott, akkor a Cattel $16 \mathrm{PF}$ teszten is alacsony értéket ért el, vagyis aki önmaga szerint nem precíz, arra a komolyság jellemzó, aki önmaga szerint pedig precíz, arra az elevenség jellemzô. Ha valaki magabiztos, az magas pontszámot adott önmagának a precizitásra, illetve, ha valaki önmaga szerint nem precíz, arra jellemző, hogy aggódó. Tendenciaszintú a kapcsolat a félénk-bátor $(\mathrm{F}(1)=3,3$, $p>0,05)$ és a nyugodt-feszült faktor esetén $(F(1)=3,09$, $\mathrm{p}>0,05)$. A többi faktor esetén nincs szignifikáns kapcsolat (tartózkodó-szívélyes: $\mathrm{F}(1)=0,84, \mathrm{p}>0,05$; konkrét gondolkodású-absztrakt gondolkodású: $\mathrm{F}(1)=0,01$, p $>0,05$; érzelmi stabilitás-érzelmi labilitás: $\mathrm{F}(1)=1,28$, p $>0,05$; domináns-alárendelódő: $F(1)=1,13, p>0,05$; szabálykövető-szabályok alól kibúvó: $\mathrm{F}(1)=0,85$, p $>0,05$; számító-érzelmi beállítottságú: $\mathrm{F}(1)=0,18$, p $>0,05$; bizalomteli-gyanakvó: $(\mathrm{F}(1)=0,30, \mathrm{p}>0,05$; praktikus-fantáziadús: $\mathrm{F}(1)=0,15, \mathrm{p}>0,05$; hagyományszeretô- kísérletező: $\mathrm{F}(1)=1,70, \mathrm{p}>0,05$; csoportemberönálló: $F(1)=0,01, \quad p>0,05$; hibatưrő-perfekcionista: $\mathrm{F}(1)=0,35, \mathrm{p}>0,05)$.

\section{A $360^{\circ}$-os visszajelzés-szorgalom kompetencia és a Cattel 16 PF faktorok kapcsolata}

Szorgalom kompetencia önértékelés esetén tendenciaszintú az összefüggés a domináns alárendelődô faktorral $(F(1)=3,3, p>0,05)$. A többi faktor esetén nincs szignifikáns kapcsolat (tartózkodó-szívélyes: $\mathrm{F}(1)=0,44, \quad \mathrm{p}>0,05$; konkrét gondolkodású-absztrakt gondolkodású: $\mathrm{F}(1)=0,64, \mathrm{p}>0,05$; érzelmi stabilitásérzelmi labilitás: $F(1)=1,63, p>0,05$; komoly-eleven: $\mathrm{F}(1)=2,5, \mathrm{p}>0,05$; szabálykövető-szabályok alól kibúvó: $(\mathrm{F}(1)=1,06, \mathrm{p}>0,05$; számító-érzelmi beállítottságú $\mathrm{F}(1)=1,42$, p>0,05; bizalomteli-gyanakvó: $(\mathrm{F}(1)=0,82$, $\mathrm{p}>0,05$; praktikus- fantáziadús: $\mathrm{F}(1)=0,07, \mathrm{p}>0,05$; egyenes-titkolózó: $F(1)=1,3$, p >0,05; magabiztos-aggódó: $\mathrm{F}(1)=2,7, \mathrm{p}>0,05$; hagyományszeretô-kísérletező: $F(1)=0,24, p>0,05$; csoportember-önálló: $F(1)=0,14$, p $>0,05$; hibatúró-perfekcionista: $F(1)=1,08, p>0,05$; a nyugodt-feszült: $\mathrm{F}(1)=0,71, \mathrm{p}>0,05)$.

A $360^{\circ}$-os visszajelzés- teljesítménymenedzsment -kompetencia és a Cattel 16 PF faktor kapcsolata

Teljesítménymenedzsment-kompetencia önértékelés esetén szignifikáns az összefüggés a következő faktorokkal: tartózkodó-szívélyes $(F(1)=4,07, p<0,05$,

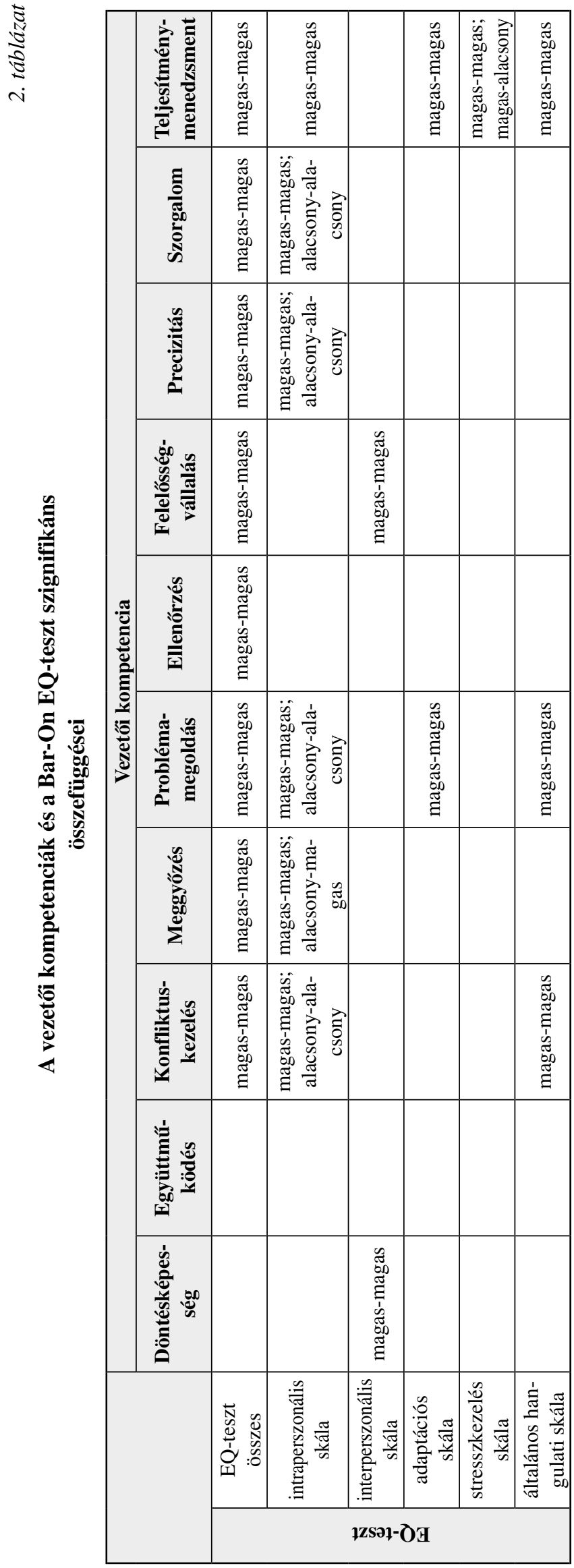




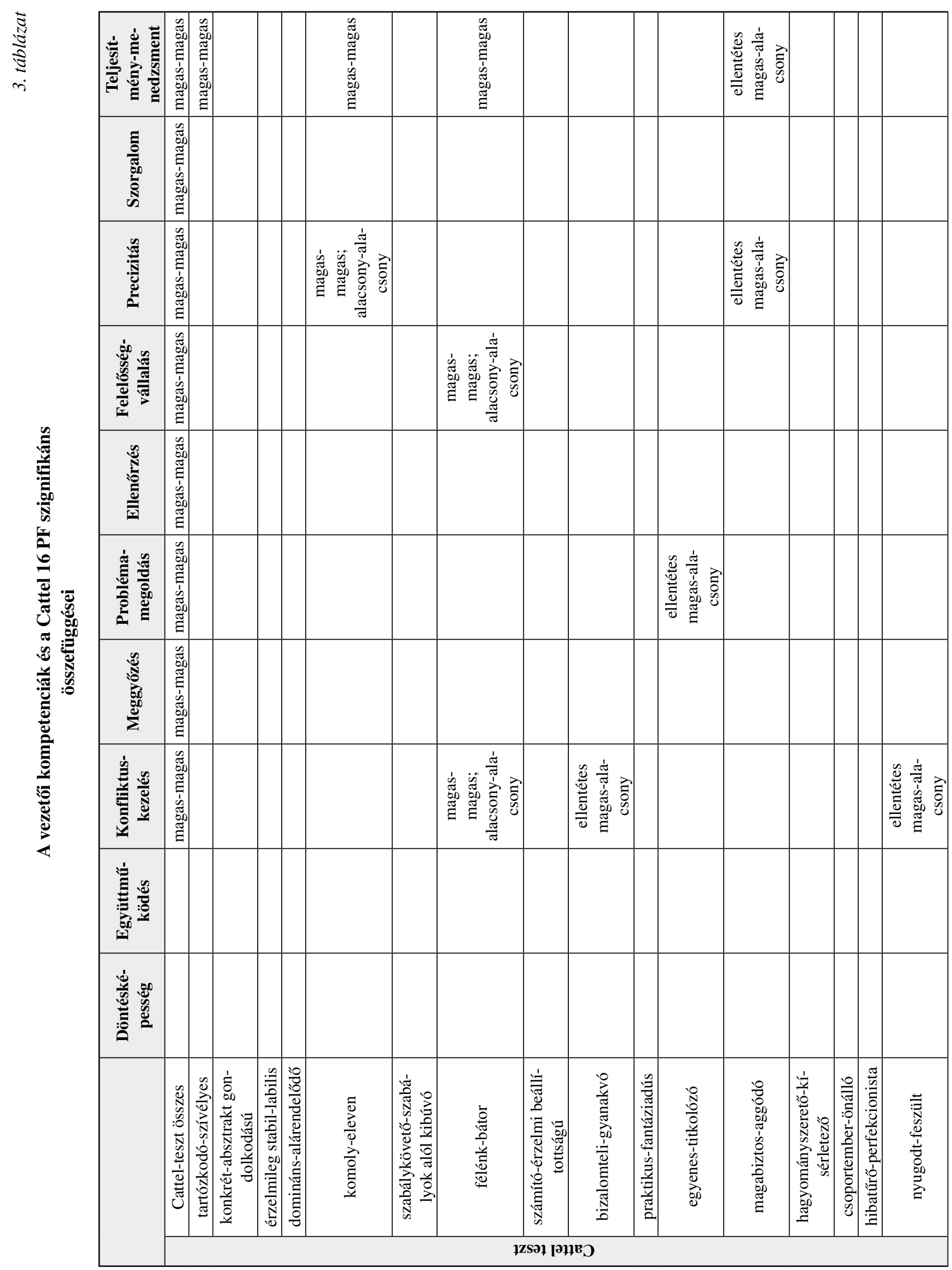


3. táblázat); komoly-eleven $(\mathrm{F}(1)=6,7, \mathrm{p}<0,05$, 3. táblázat); félénk-bátor $(\mathrm{F}(1)=5,07, \mathrm{p}<0,05,3$. táblázat $)$; magabiztos- aggódó $(\mathrm{F}(1)=4,9, \mathrm{p}<0,05,3$. táblázat $)$. Azok, akik magasra értékelték önmagukat a teljesítményértékelés során szívélyesek, elevenek, bátrak és magabiztosak. Tendenciaszintú az összefüggés a praktikus-fantáziadús faktor esetén $(\mathrm{F}(1)=3,2, \mathrm{p}>0,05)$. A többi faktor esetén nincs szignifikáns kapcsolat (konkrét gondolkodású-absztrakt gondolkodású: $\mathrm{F}(1)=0,54$, p $>0,05$; érzelmi stabilitás-érzelmi labilitás: $\mathrm{F}(1)=0,27$, $\mathrm{p}>0,05$; domináns-alárendelődó: $\mathrm{F}(1)=1,79, \mathrm{p}>0,05$; szabálykövetô-szabályok alól kibúvó: $(\mathrm{F}(1)=2,42$, $\mathrm{p}>0,05$; számító-érzelmi beállítottságú: $\mathrm{F}(1)=1, \mathrm{p}>0,05$; bizalomteli-gyanakvó: $(\mathrm{F}(1)=0,52, \mathrm{p}>0,05$; egyenestitkolózó: $\mathrm{F}(1)=0,59, \mathrm{p}>0,05$; hagyományszeretô-kísérletező: $F(1)=1,72, \quad p>0,05$; csoportember-önálló: $\mathrm{F}(1)=1,34, \mathrm{p}>0,05$; hibatúró-perfekcionista: $\mathrm{F}(1)=1,12$, $p>0,05$; a nyugodt-feszült: $F(1)=0,04, p>0,05)$.

\section{Következtetés}

A vizsgált vezetôi kompetenciák $360^{\circ}$-os visszajelzés önértékelése esetén életkor szerint nincs szignifikáns különbség. Carless és munkatársai (1998) is hasonló eredményre jutottak a $360^{\circ}$-os visszajelzés eredményei alapján, bár ốk nemcsak az önértékelést vették figyelembe. A vezetối kompetenciák külön elemzésével megfigyelhető, hogy az együttmúköóes területén különböznek a csoportok. A fiatal korosztály szerint ók jól múködnek együtt másokkal, míg az idôsebb korosztály tagjai önbevallásuk szerint nem együttmúködők.

$\mathrm{Az}$ is megfigyelhető, hogy az érzelmi intelligencia szintje összefüggésben van a vezetôi kompetenciák önértékelésének szintjével. A konfliktuskezelés, a meggyôzési készség, a problémamegoldás, az ellenőrzés, a felelősségvállalás, a precizitás, a szorgalom és a teljesítménymenedzsment esetén, ha valaki önmaga szerint jó ezekben a vezetói kompetenciákban, akkor magas EQ-pontszámot ért el.

A jó konfliktuskezelő, jó meggyőzési készséggel rendelkező, jó problémamegoldó, precíz, szorgalmas vezetốk éntudatosak, nagy az önbecsülésük, függetlenek, törekszenek az önmegvalósításra, és önérvényesítók is egyben, illetve, ha nem tartják önmagukat annak, akkor ezek az érzelmi-intelligencia komponensek nem jellemzók rájuk. A teljesítménymenedzsment-feladatokat kiválóan végző vezetốk pedig ezen a skálán is magas pontszámot értek el, azonban azt nem mondhatjuk el, hogy a teljesítménymenedzsmentet gyengén végzóknek például alacsony lenne az önbecsülésük vagy az önérvényesítésük. Megfigyelhető az is, hogy a magas döntésképességgel rendelkező és felelősség- teljes vezetók empatikusak, jellemző rájuk az interperszonális kapcsolatok építése és a társas felelôsségtudat. A problémamegoldásban kiváló vezetốk könnyen alkalmazkodnak, rugalmasak, a realitásérzékük erôs. Ennél a két skálánál a vezetôi kompetenciák és az EQskálák hasonló területeket mérnek. Az összefüggés innen is eredhet a felelősségvállalás kompetencia-társas felelősségvállalás esetén, vagy a problémamegoldás kompetencia és az adaptációs skála problémamegoldás komponens esetén. Ez az eredmény azt is alátámaszthatja, hogy a vezetôi kompetenciák mérése megfelelóen történt a standard eszközhöz való viszonyítás alapján. A teljesítménymenedzsment-feladatokat kiválóan ellátók jól túrik a stresszhatásokat, stressztolerancia és impulzuskontroll jellemző rájuk. A gyengén teljesítménymenedzselók pedig szintén magas stressztűréssel rendelkeznek. Ebból a szempontból a csoportok között nincs különbség, vagyis a stresszkezelés nem befolyásolja valószínúleg ennek a feladatnak az ellátását. A konfliktusokat jól kezelókre, a problémamegoldókra, a teljesítménymenedzsmentet jól végzókre az is jellemzó, hogy optimista és boldog személyek.

A Cattel 16 PF teszt eredménye alapján láthatjuk, hogy aki magas pontszámot ért el, az önbevallása szerint jó konfliktuskezelő, meggyőző, jó problémamegoldó, jól ellenôrző, felelôsségteljes, precíz, szorgalmas, és a teljesítménymenedzsment-feladatokat megfelelôen ellátó vezetố. A teljesítménymenedzsmentet jól végző vezetốk jellemzóen szívélyesek, elevenek, bátrak és magabiztosak. A precíz vezetókre jellemzó az elevenség és a magabiztosság. A nem precíz vezetókre pedig a komolyság. A felelósségteljes vezetók bátrak, a felelősségvállalás hiányában pedig a félénkség jellemzi a vezetóket. A rossz problémamegoldó vezetốk titkolózók. A jó konfliktuskezelő vezetốk bátrak, nyugodtak és bizalommal telik, a gyenge konfliktuskezelő vezetôk pedig gyanakvók és feszültek.

Ezek az eredmények segíthetnek a vezetố fejlesztésében. A vezetói kompetenciák fejlesztése segítheti az érzelmi intelligencia fejlôdését és fordítva, az érzelmi intelligencia megfelelő komponenseinek fejlesztése a vezetôi kompetenciák bizonyos fejlődését eredményezheti. Bizonyos személyiségtényezók megfelelő fejlesztése egyes vezetôi kompetenciák fejlődését is eredményezheti. Az eredmények ugyan egy pilot programból származnak, így a minta elemszáma ilyen szintú következtetésekre nem adhat okot teljes mértékben, de a további vizsgálatok kiterjesztésével ez a kérdés is megválaszolhatóvá válhat, és a vezetôi kompetenciák fejlesztésének eszköztára is növekedhet ezen elképzelés alapján. 


\section{Lábjegyzet}

Köszönetnyilvánítás:

„A kutatás a TÁMOP 4.2.4.A/2-11-1-2012-0001 azonosító számú Nemzeti Kiválóság Program - Hazai hallgatói, illetve kutatói személyi támogatást biztosító rendszer kidolgozása és múködtetése konvergenciaprogram címú kiemelt projekt keretében zajlott. A projekt az Európai Unió támogatásával, az Európai Szociális Alap társfinanszírozásával valósul meg."

Köszönöm a Linamar Hungary Zrt.-nek, a Humánpolitikai osztálynak és Parászka Tibor humánpolitikai igazgatónak, hogy biztosították az adatfelvételt és segítették munkámat.

\section{Felhasznált irodalom}

Atkins, P.W.B. - Wood, R.E. (2002): Self-versus other's ratings as predictors of assessment center rating: validation evidence for 360-degree feedback programs. Personnel Psychology, 55.: p. 871-904.

Bakacsi Gy. (1998): Szervezeti magatartás és vezetés. Budapest: Közgazdasági és Jogi Könyvkiadó

Bar-On, R. (1997): Bar-On Emotional Quotient Inventory (EQ-i): Technical manual. Toronto: Multi Health Systems

Bar-On, R. (2004): The Bar-On Emotional Quotient Inventory (EQ-I): Rationale, description and summary of psychometric properties. in: Glenn Geher (ed.): Measuring emotional intelligence: Common ground and controversy. Hauppauge: Nova Science Publishers: p. 111-142.

Boyatzis, R.E. (1982): The Competent Manager-Modell for Effective Performance. Chichester: John Wiley and Sons

Brown, R.B. (1994): Reframing the competency debate. Managment Learning: p. 289-300.

Carless, S. - Mann, L. - Wearing, A. J. (1998): Leadership, managerial performance and 360-degree feedback. Journal of Applied Psychology, 82(2.): p. 281-292.

Cattel, R.B. - Eber, H.W. - Tatsuoka, M.M. (1970): Handbook for the Sixteen Personality Factor Questionnaire (16PF). Champaign, IL: Institute for Personality and Ability Testing

Chong, C. - Ho, Y. - Tan, H. - Ng,K. (2001): A Practical Model for Identifying and Assessing Work Competencies. in: http://www.esc.edu/MDF (Vol.3, No.1.2000).

Eraut, M. (1994): Developing professional knowledge and competence. London: Falmer Press

Freudenberg, $\quad$. . (2004): Competency modeling. in: http://111.ipmaac.org/ptcss/PTC\%20Competency\%20 Modeling\%20Presentation.ppt.

Goleman, D. (1998): What Makes a Leader. Harvard Business Review, Vol. 76, No. 11-12.: p. 93-104.

Hegyi H. (2012): Személy(iség) a kompetenciák mögött. Doktori értekezés. Pécs: Pécsi Tudományegyetem, Alkalmazott pszichológia Program

Jakó M. (2003): A kompetencia fogalmának értelmezési lehetőségei Magyarországon, a kompetenciák elismerésére tett kísérletek az Európai Unióban. http:// www.Easylearning.hu/magyar/easyherald/2003maj/ jakocikk1.html Letöltés dátuma: 2013. 02.13.
Klemp, G.O. - McClelland, D.C. (1986): What characterizes intelligent functioning among senior managers? Practical Intelligence. Cambridge: Cambridge University Press

Kốvári Gy. (1991): Gazdálkodás az emberi eróforrásokkal. Felsőfokú személyügyi szaktanfolyam jegyzék. Budapest: Országos Munkaügyi Központ

Legge, D. - Barber, J.P. (1982): Információ és készség. Budapest: Gondolat Kiadó

London, M. - Smither, J.W. (1995): Can multi-score feedback change perceptions of goal accomplishment selfevalutions, and performance related outcomes? Personnel Psychology, 48.: p. 803-839.

Martin, G. - Staines, H. (1994): Managerial competences in small firms. Journal of Managment Developent, 13:7: p. 23-24.

Mayer, J.D. - Salovey, P. - Caruso, D.R. (2000): Competing models of emotional intelliegnce. in: R. J. Stenberg (Ed.): Handbook of Human Intelligence. New York: Cambridge University Press: p. 396-420.

McClelland, D.C. - Boyatzis, R.E. (1980): Opportunities for Counselors from the Competency Assessment Movement. The Personnel and Guidance Journal, Jan.: p. 368-372.

Meier, H. (2001): Integrierte Führungskraftentwicklung. Zeitschrift für Unternehmensentwicklung and Industrial Engineering. Vol. 50, No.1.: p. 33-35.

Mohácsi G. (1996): Kompetencia modell nemzetközi környezetben. Humánpolitikai Szemle. Vol. 7, No. 11.: p. 3.

Neubauer, A.C. - Freudenthaler, H.H. (2005): Models of Emotional Intelligence. in: Emotional Intelligence. An international handbook. Eds.: Schulze, R., Roberts, R. D., Hogrefe and Huber Publishers

Pató G.Sz.B. (2006): Kompetenciák, feladatok logisztikai rendszerekben. Doktori (Ph.D) értekezés. Veszprém: Pannon Egyetem Gazdálkodási és Szervezéstudományok Doktori Iskola

Spencer, L. -McClelland, D. - Spencer, S. (1990): Competency Assessment Methods, History and State of the Arts. Boston: Hay/McBer Research Paper

Spencer, I.M.Jr. - Spencer S.M. (1993): Competence at work. New York: John Wiley Sons

Sveiby, K.E. (2001): Szervezetek új gazdasága: a menedzselt tudás. Budapest: Közgazdasági és Jogi Könyvkiadó

Szászvári K. (2008): Humán eróforrás gazdálkodás modul. Munkaerő-piaci ügynök képzés. Modulfüzet. Pécs

Szelestey J. (2012): A kompetencia modell kidolgozásának módszertana. Szakdolgozat

Szögi Z. (1997): Kompetenciavizsgálat a MALÉV Rt. középvezetôinél. Szakdolgozat. Budapest.

Takács I. (2010): A halogatás jellemzói a felsôoktatásban. Habilitációs dolgozat.

TóthnéS.G. (szerk.) (2000): Humán eróforrások gazdaságtana. Miskolc: Bíbor Kiadó

Woodruffe, C. (1993): What Is Meant by a Competency?, Leadership and Organization Development Journal, Vol. 14 Is: 1: p. 29-36. 